\begin{tabular}{ll}
\hline Innowacje w Pielęgniarstwie i Naukach o Zdrowiu & $\mathbf{4 ( 1 ) / 2 0 1 6}$
\end{tabular}

ISSN 2451-1846

DOI: http://dx.doi.org/10.21784/IwP.2016.024

Klaudia Rutka

${ }^{1}$ Wojewódzki Szpital Specjalistyczny im. błogosławionego księdza Jerzego Popiełuszki we Włocławku, Oddział Anestezjologii i Intensywnej Terapii;

\title{
Rola i zadania szpitalnego koordynatora transplantacyjnego
}

\section{The role and tasks of the hospital transplant coordinator}

\begin{abstract}
Streszczenie
Jednym z największych osiągnięć współczesnej medycyny jest rozwój transplantologii. Dzięki niej poprawiła się jakość i przeżycie wielu osób, które nie mogą funkcjonować z niewydolnym narządem. Transplantacja jest dla nich nadzieją na nowe, lepsze życie. Tematyka ta wywołuje wiele kontrowersji wśród społeczeństwa, gdyż większość narządów pozyskiwana jest od osób zmarłych. Procedura pobrania narządu od dawcy wymaga zaangażowania $\mathrm{w}$ pracę wielu osób, pracujących $\mathrm{w}$ różnych instytucjach w całej Polsce. Szpitale mają prawny obowiązek zgłaszania potencjalnych dawców, którzy najczęściej przebywają w Oddziałach Intensywnej Terapii, gdzie roztacza się opiekę nad zmarłym potencjalnym dawcą narządów. Dawcy są to najczęściej osoby młode, a ich śmierć jest szokiem dla osób bliskich, którym ciężko wypowiedzieć się na temat woli zmarłego na dawstwo narządów. Lokalny koordynator transplantacyjny jest osobą, która zajmuje się monitorowaniem potencjału dawstwa na obszarze swojego działania. Czuwa nad sprawnym przebiegiem całości działań związanych z wysunięciem podejrzenia śmierci mózgu i jej potwierdzenia. Jego zadaniem jest zgłoszenie potencjalnego dawcy do Centrum Organizacyjno-Koordynacyjnego ds. transplantacji "Poltransplant" i dokonanie autoryzacji pobrania. Wspomaga współpracowników w opiece nad dawcą do momentu pobrania narządów. Organizuje pobranie wielonarządowe w swoim szpitalu. Posiada kwalifikacje, wiedzę i umiejętności niezbędne w realizacji wyznaczonych zadań. Jest to osoba, która kreuje wizerunek transplantologii w społeczeństwie.
\end{abstract}

\footnotetext{
Abstract

One of the greatest achievements of modern medicine is the development of transplantology. It improved survival and quality of life of people with organ failure. It gives them hope for a new and better life. This issue of is controversial among the public as most organs are obtained from deceased donors. The procedure of organ procurement from a donor requires commitment of many individuals working in various institutions throughout the country. Hospitals have a legal obligation to report potential donors whoare usually managed in the intensive care units. Organ donors include mostly young people whose death is a shock to relatives, for whom it is hard to comment on the will of the patient regarding organ donation. A Local transplant coordinator is a person monitoring institutional organ donation within the administered area. They supervise activities related to the confirmation of brain death, notify the Local Organ Procurement Organisation (Poltransplant) about potential donors.They support colleagues in the care of the donors, organise and authorise taking organs from deceased donors in their institutions. Coordinators have the qualifications, knowledge and skills necessary to perform those tasks. They are the people who create the image of transplantology in society.
} 
Słowa kluczowe: transplantologia, koordynator transplantacyjny, dawca narządów

Keywords: transplantology, transplant coordinator, organ donation

\section{Wstęp}

Transplantacje narządów mimo ogromnego rozwoju medycyny bardzo często są jedynym skutecznym sposobem leczenia dla chorych z niewydolnością narządów. Jest to szansa, która umożliwia powrót do zdrowia i funkcjonowania w społeczeństwie. Narząd do transplantacji jest darem jaki możemy otrzymać jedynie od drugiego człowieka. Liczba narządów do transplantacji jest niewystarczająca, aby pokryć zapotrzebowanie na leczenie tą metodą. W 2015 roku na Krajowej Liście Oczekujących było 2550 chorych, natomiast przeszczepiono jedynie 1432 narządy. Nad całością procesu pobierania i przeszczepiania czuwają koordynatorzy transplantacyjni, których można podzielić na lokalnych, regionalnych i zatrudnionych na szczeblu centralnym tzw. koordynatorzy Poltransplantu [1,2,3]. Osoba pełniąca funkcję koordynatora posiada szeroką wiedzę m.in. z zakresu transplantologii, psychologii, etyki. Koordynator zna obowiązujące przepisy prawne i je respektuje. Organizuje pracę wielodyscyplinarnych zespołów zajmujących się identyfikacją, opieką nad potencjalnym dawcą narządów, pobieraniem i przeszczepianiem narządów [4].

Celem niniejszego opracowania będzie przedstawienie zadań szpitalnego/lokalnego koordynatora transplantacyjnego pracującego w szpitalu z potencjałem donacyjnym, w którym narządy pobiera się od zmarłych po stwierdzonej śmierci mózgu.

\section{Kilka słów o dawcach narządów}

Dawcą narządów określamy osobę żywą lub zmarłą, od której pobiera się komórki tkanki lub narządy. Pobrania można dokonać jeżeli dawca za życia nie wyraził sprzeciwu [4]. Pobranie narządów jest dopuszczalne jeżeli została stwierdzona śmierć mózgu. Śmierć mózgu jest trwałym i nieodwracalnym ustaniem czynności mózgu. Jest procesem, który uniemożliwia funkcjonowanie organizmu jako całości [6]. Narządy można również pobrać w przypadku stwierdzenia zgonu spowodowanego nieodwracalnym zatrzymaniem krążenia. Zatrzymanie krążenia bardzo szybko powoduje śmierć komórek mózgowych i ostatecznie prowadzi do śmierci mózgu. Narządy uzyskiwane do przeszczepienia są bardziej trwałe na niedotlenienie i dłużej niż mózg utrzymują swoją funkcjonalność. W przypadku NZK (nagłego zatrzymania krążenia) daje to możliwość pobrania ich i skutecznego przeszczepienia potrzebującemu biorcy [7]. Komórki, tkanki lub narządy mogą być również pobrane od dawcy żywego. Warunkiem jest pokrewieństwo dawcy i biorcy lub istnienie więzi emocjonalnej. W przypadku dawstwa od żywej osoby pobranie narządu musi być zasadne i celowe, a kandydat na dawcę przechodzi szereg odpowiednich badań i zostaje poinformowany o ryzyku związanym z zabiegiem, a także musi wyrazić świadomą zgodę [4].

\section{Koordynator transplantacyjny - prawne aspekty wykonywania zawodu}

Koordynator transplantacyjny jest to osoba, która posiada odpowiednie wykształcenie i kwalifikacje oraz jest uprawniona do koordynacji pobrania i przeszczepienia narządów. Zadania wynikają z ustawy o pobieraniu, przechowywaniu i przeszczepianiu komórek, tkanek i narządów. Koordynacja pobierania i przeszczepiania komórek, tkanek i narządów jest procesem wieloetapowym na który składa się uzgodnienie dotyczące czasu, miejsca, sposobu pobrania i przekazania komórek tkanek lub narządów do podmiotu leczniczego lub banku tkanek. Osoba uprawniona nadzoruje przebieg całego procesu. Stanowisko to może objąć osoba, 
która posiada wyższe wykształcenie medyczne i ukończone szkolenie podyplomowe dla koordynatorów transplantacyjnych. W związku z rozwojem transplantologii i ciągłym postępem $\mathrm{w}$ związanych z nią dziedzinach nauki, koordynatorzy zobowiązani są do podjęcia szkolenia wstępnego, dedykowanego dla osób rozpoczynających pracę na stanowisku. Szkolenia ustawiczne skierowane są do wszystkich koordynatorów i należy nie rzadziej niż raz co 2 lata odbyć taką formę doskonalenia. Szkolenia uaktualniające odbywa się w przypadku zmian procedur lub rozwoju wiedzy naukowej. Szkolenia mają na celu zdobycie wiedzy i umiejętności niezbędnych do realizacji zadań $[4,5]$.

\section{Zakres wiedzy i umiejętności niezbędnych w pracy lokalnego koordynatora transplantacyjnego}

Koordynator powinien posiadać kompletną wiedzę m.in. z zakresu transplantologii klinicznej, immunologii, intensywnej terapii. Wymagane jest także posiadanie wiedzy z zakresu nauk społecznych, prawa a także znajomość organizacji polskiego i europejskiego systemu transplantacyjnego. Osoba obejmująca to stanowisku posiada szeroką wiedzę z zakresu psychologii klinicznej. Umożliwia to prawidłowe przeprowadzenie rozmowy $\mathrm{z}$ rodziną potencjalnego dawcy narządów i uzyskanie autoryzacji pobrania [8].

Koordynator przede wszystkim cechuje się kreatywnością; to osoba która samodzielnie prowadzi program donacyjny w szpitalu. Posiada umiejętność organizowania, prowadzenia i dokumentowania pracy całego wielodyscyplinarnego zespołu zaangażowanego w opiekę nad dawcą od momentu wysunięcia podejrzenia śmierci mózgu kończąc na pobraniu narządów od dawcy. Posiada także wiedzę z zakresu statystyki medycznej i sporządza miesięczne raporty statystyczne. Jednym z zadań koordynatorów jest kształtowanie wizerunku transplantologii w społeczeństwie poprzez nauczanie i prowadzenie kampanii promocyjnych oraz organizowanie szkoleń dla współpracowników [8].

\section{Zakres zadań koordynatora}

\section{Identyfikacja dawcy, diagnostyka i rozpoznanie śmierci}

Koordynator transplantacyjny jest osobą, która identyfikuje potencjalnych dawców. Zmarłych w mechanizmie śmierci mózgu możemy spodziewać się wszędzie tam, gdzie pacjenci mogą być wentylowani mechanicznie. Najczęściej przebywają oni w oddziałach intensywnej terapii (OIT). Przyjmuje się, że statystycznie na jedno łóżko w OIT przypada jedna śmierć mózgu w ciągu roku. Liczba ta zwiększa się jeżeli w szpitalu jest oddział neurochirurgii, neurologii, gdy leczeni są pacjenci z urazami głowy. Przyjmuje się, że 41\% zmarłych w mechanizmie śmierci mózgu staje się faktycznym dawcą narządów. Główną przyczyną zgonu są choroby naczyń mózgowych i urazy czaszkowo-mózgowe.

Rolą koordynatora jest wyszukiwanie potencjalnych dawców i skonsultowanie tego faktu z lekarzem, który może wysunąć podejrzenie śmierci mózgu. Kryteria i sposób stwierdzania nieodwracalnego ustania czynności mózgu zawarte są w Obwieszczeniu Ministra Zdrowia. Procedura składa się z dwóch etapów. Pierwszy z nich to wysunięcie podejrzenia śmierci mózgu i stwierdzenie, czy chory jest w śpiączce, której przyczynę jesteśmy w stanie ustalić i nie wykazuje spontanicznej czynności oddechowej. Ponadto wystąpiło pierwotne lub wtórne uszkodzenie mózgu, które jest nieodwracalne wobec zastosowanego leczenia i upływu czasu. W tym czasie należy również wykluczyć zatrucie; osoba nie może być pod wpływem leków, które zaburzają świadomość. Chory nie może być w stanie hipotermii, musi mieć wykluczone zaburzenia metaboliczne. Należy stwierdzić, że osoba nie jest noworodkiem poniżej 7 dnia życia. Po etapie stwierdzeń i wykluczeń należy zastosować czas obserwacji wstępnej, 
który jest zależny od wieku i przyczyny uszkodzenia mózgu. Po tym okresie przechodzi się do etapu drugiego, który polega na stwierdzeniu braku odruchów z nerwów czaszkowych i braku czynności ośrodka oddechowego $\mathrm{w}$ trakcie próby bezdechu. Jest to szereg badań neurologicznych, które dwukrotnie wykonuje lekarz specjalista w określonych odstępach czasu. W pewnych przypadkach, kiedy brak jest możliwości przeprowadzenia któregokolwiek z testów, należy posiłkować się badaniami instrumentalnymi. Badanie te są obligatoryjne również w przypadku niektórych określonych mechanizmów uszkodzeń mózgu i w odniesieniu do dzieci do drugiego roku życia. Szczegółowy sposób przeprowadzenia omawianych badań opisują akty wykonawcze. Ostatnim etapem jest powołanie komisji, która składa się z trzech lekarzy specjalistów, w tym jednego specjalisty anestezjologii i intensywnej terapii, specjalisty neurologa lub neurochirurga i specjalisty dowolnej dziedziny medycznej. Komisja ta jest uprawniona do stwierdzenia zgonu po zapoznaniu się $\mathrm{z}$ aktualnym stanem pacjenta i sprawdzeniu, czy na każdym etapie procedury zostały spełnione wszystkie warunki. To upoważnia do komisyjnego stwierdzenia zgonu w mechanizmie śmierci mózgu. Godzina podpisania protokołu jest godziną zgonu i od tego momentu ustaje obowiązek terapeutyczny. Procedurę wykonuje się nie tylko pod kątem dawstwa narządów, lecz również po to, aby zaniechać uporczywej terapii zmarłego. Przy istnieniu jakiejkolwiek wątpliwości komisja odstępuje od stwierdzenia zgonu i kontynuuje terapię pacjenta. Jeżeli stwierdzono zgon zmarły może być rozpatrywany jako potencjalny dawca narządów. Rolą koordynatora jest pomoc w sprawnym wykonaniu procedur. W wielu ośrodkach w Polsce to lekarze pełnią funkcję koordynatorów transplantacyjnych i w takim przypadku są najczęściej osobami, które aktywnie uczestniczą w procedurze orzekania śmierci mózgu [8,9,10,11].

\section{Kwalifikacja dawcy i autoryzacja pobrania}

Kolejnym etapem pracy koordynatora jest wstępne stwierdzenie, czy zmarły nie ma bezwzględnych przeciwwskazań, aby zostać dawcą narządów, gdyż istnieje wysokie ryzyko przeniesienia chorób zakaźnych czy nowotworowych do biorcy narządu. W tym momencie najczęściej koordynator lokalny zgłasza koordynatorowi regionalnemu potencjalnego dawcę narządów. Koordynator regionalny jest osobą, która wspiera koordynatora szpitalnego w działaniach, kontaktuje się również z centrum koordynacyjnym „Poltransplant”. Dane zmarłego potencjalnego dawcy wpisywane są do serwisu „rejestry.net” i uzupełniane przez koordynatorów na bieżąco o aktualne dane medyczne i wyniki badań. Prowadzone jest to w taki sposób, aby osoby kwalifikujące narząd do pobrania i przeszczepienia mogły podjąć decyzję o wstępnej kwalifikacji narządu do pobrania. Ostateczną decyzję podejmuje chirurg badający dany narząd w trakcie pobrania[8].

Koordynatorzy zobowiązani są do autoryzacji pobrania. Polega to na ustaleniu czy zmarły za życia nie wyraził sprzeciwu na dawstwo narządów. Istnieją trzy formy za pomocą których można wyrazić sprzeciw: wpis do Centralnego Rejestru Sprzeciwów na pobranie komórek, tkanek i narządów ze zwłok ludzkich, oświadczenie pisemne z własnoręcznym podpisem lub oświadczenie ustne wypowiedziane w obecności dwóch świadków i pisemnie przez nich potwierdzone. Jeżeli dawcą jest dziecko taki sprzeciw mogą zgłosić prawni opiekunowie małoletniego przed śmiercią dziecka. Osoby, które ukończyły 16 rok życia uprawnione są do samodzielnego złożenia sprzeciwu[4].

Koordynator regionalny przekazuje informacje, czy zmarła osoba nie złożyła oficjalnego sprzeciwu w Centralnym Rejestrze Sprzeciwów. Jeżeli taki sprzeciw istnieje, odstępuje się od dalszych czynności prowadzących do pobrania narządów, a także osobę zmarłą odłącza się od respiratora[8]. 
Jednym z najtrudniejszych momentów w pracy koordynatora jest rozmowa z rodziną zmarłego. Śmierć bliskiej osoby jest jednym z najtrudniejszych przeżyć w życiu człowieka, a adaptacja do życia po stracie jest procesem długotrwałym. Najwcześniejszą fazą żałoby jest reakcja wstrząsu. Osoba prowadząca rozmowę musi być przygotowana na najróżniejsze emocje i zachowania ze strony rodzin osób zmarłych. Autoryzacja pobrania jest potwierdzeniem, że pobranie narządów i tkanek było wolą zmarłego. Komunikowanie z rodziną nie ma na celu jedynie uzyskania autoryzacji pobrania. Koordynator powinien być wsparciem dla rodziny w tych trudnych chwilach, informować jak będzie wyglądała dalsza procedura, co stanie się z ciałem zmarłego po pobraniu. Takie rozmowy wymagają od koordynatora wielu pokładów empatii, zrozumienia, cierpliwości. Umiejętność prowadzenia rozmowy i nie ograniczenie jej czasu ułatwia relacje z rodziną [12].

Jeżeli komórki, tkanki lub narządy mają być pobrane od osoby, która zmarła w wyniku czynu zabronionego należy uzyskać również akceptację prokuratora lub sądu rodzinnego na pobranie. Po uzyskaniu autoryzacji przeprowadza się wiele badań u potencjalnego dawcy, aby wykluczyć ryzyko przeniesienia chorób do organizmu biorcy. Zbiera się szczegółowy wywiad, analizuje wyniki badań biochemicznych, wirusologicznych, wykonuje się badanie przedmiotowe $\mathrm{z}$ pomiarami ciała, jak również wiele badań obrazowych $\mathrm{w}$ celu oceny narządów do przeszczepienia. Wiele z tych zadań wykonywanych jest równoczasowo, dlatego dużo zależy od organizacji pracy i sprawnego działania. Najczęściej na tym etapie koordynator prosi lekarza chirurga o pobranie węzłów chłonnych do typowania tkankowego; badanie to wykonuje się w nielicznych ośrodkach i jest czasochłonne. W czasie przygotowań do pobrania, oczekiwania na wyniki badań, szukania odpowiednich biorców zespół Oddziału Intensywnej Terapii otacza profesjonalną opieką dawcę narządów [8,13].

\section{Opieka nad dawcą}

Opieka nad dawcą ma na celu utrzymanie narządów dawcy w jak najlepszym stanie do momentu ich pobrania $\mathrm{z}$ organizmu. Na tym etapie główne problemy to zaburzenia wentylacji, hipowolemia, zaburzenia ciśnienia tętniczego, trudność w utrzymaniu termoregulacji, wystąpienie zaburzeń hormonalnych i zakażeń. Zaburzenia te związane są ze śmiercią mózgu. Potencjalny dawca narządów ma zastosowane szerokie monitorowanie podstawowych parametrów i na ich podstawie modyfikuje się leczenie. Na tym etapie nie jest to jednak leczenie dawcy, a jedynie leczenie narządów, aby w jak najlepszym stanie trafiły do biorców. Opieka nad zmarłym dawcą wymaga wiele wysiłku i wkładu pracy zarówno lekarza jak i pielęgniarek zaangażowanych $\mathrm{w}$ opiekę. Czas ten poświęca się na wykonanie niezbędnych badań i jak najlepsze przygotowanie do pobrania [9].

\section{Koordynacja i organizacja pobrania wielonarządowego}

Zadaniem lokalnego koordynatora jest współdziałanie z zespołem zajmującym się dawcą oraz koordynatorem na szczeblu regionalnym i centralnym w taki sposób, aby praca przebiegała sprawnie i efektywnie. Całość działań związanych z pobraniem narządu od dawcy to kwestia wielu godzin pracy, osoba zajmująca się koordynacją musi być dyspozycyjna. Koordynator lokalny jest wsparciem dla pracowników szpitala, udziela wyjaśnień, rozdziela zadania, wyjaśnia wątpliwości. Koordynator musi być poinformowany o tym, które narządy zostaną pobrane i przez jaki zespół. Wspólnie z koordynatorem regionalnym ustalana jest godzina rozpoczęcia pobrania, która jest zależna przede wszystkim od stanu zmarłego potencjalnego dawcy narządów, możliwości dotarcia na miejsce pobrania zespołów pobierających i możliwości dotarcia do wyznaczonych szpitali potencjalnych biorców narządów. Koordynator lokalny 
przygotowuje blok operacyjny na czas pobrania i organizuje jego pracę w taki sposób, aby jak najmniej zaburzyć jego codzienne funkcjonowanie. W związku z powyższym godziny pobrania to często godziny nocne. Jego zadaniem jest zorganizowanie obsady lekarza anestezjologa, pielęgniarki anestezjologicznej i instrumentariuszki a także salowej na czas pobrania oraz powiadomienie zespołu Oddziału Intensywnej Terapii, w którym przebywa dawca o godzinie przewiezienia dawcy na blok. Koordynator sprawdza czy przygotowano niezbędne materiały i sprzęt na czas wykonania procedury. Czas od momentu wysunięcia podejrzenia śmierci mózgu do pobrania narządów to kilkanaście do kilkudziesięciu godzin. W działania te zaangażowane jest około 100 osób.

Koordynator musi na czas skompletować i przygotować dokumentację dawcy. Muszą wniej znaleźć się wszystkie wyniki badań laboratoryjnych i obrazowych, protokół przeprowadzonej diagnostyki śmierci mózgu, protokół komisyjnego stwierdzenia śmierci mózgu, wydruk z Centralnego Rejestru Sprzeciwów a także karty obserwacji dawcy z OIT w celu oceny zaburzeń ustrojowych, mogących mieć wpływ na jakość narządów. Po przybyciu zespołów transplantacyjnych koordynator ustnie przekazuje niezbędne informacje o dawcy i odpowiada na pytania lekarzy pobierających narządy. Godzina pobrania to godzina nacięcia skóry dawcy przez zespół rozpoczynający zabieg. Zabieg pobrania trwa kilka godzin i zależy od tego ile i jakie narządy zostają pobierane. Po pobraniu należy dopilnować, aby zespoły transplantacyjne pozostawiły zwłoki z należytym szacunkiem oraz uzupełniły dokumentację dawcy o protokół pobrania narządów. Po pobraniu koordynator otrzymuje informacje o tym, jakie narządy zostały przeszczepione i czy podjęły swoje funkcje. Powyższą informację przekazuje rodzinie dawcy oraz zespołowi, który był zaangażowany w opiekę i przygotowanie do pobrania. Dzięki pozytywnym informacjom zwrotnym zespół ma możliwość zauważenia celowości swoich działań. Personel uświadamia sobie sprawę z tego, że śmierć jednej osoby dała możliwość życia innym ludziom, którzy otarli się o śmierć $[8,9]$.

\section{Monitorowanie potencjału dawstwa, dokumentowanie i opracowania statystyczne, edukacja i promocja}

Koordynator lokalny poza zadaniami związanymi z koordynacją pobrania wielonarządowego zajmuje się prowadzeniem na rzecz Poltransplantu sprawozdań i zestawień statystycznych dotyczących potencjału dawstwa w szpitalu. Zgłaszanie możliwości pobrania jest prawnym obowiązkiem szpitali. Głównym zadaniem jest zwiększenie liczby pobieranych narządów. Koordynator ma również obowiązek prowadzić szkolenia, edukować i promować ideę dawstwa narządów[8].

\section{Wnioski}

Koordynator lokalny jest to osoba wykwalifikowana, kompetentna, którą cechuje wysoki poziom wiedzy z transplantologii, bardzo dobrze zna obowiązujące akty prawne z tego zakresu i je respektuje. Uczestniczy w identyfikacji potencjalnych dawców, współdziała z lekarzami w celu przeprowadzenia diagnostyki śmierci mózgu. Po komisyjnym stwierdzeniu zgonu uczestniczy w opiece nad potencjalnym dawcą, wspiera i motywuje zespół do pracy. Współpracuje z Centrum - Organizacyjno - Koordynacyjnym ds. transplantacji „Poltransplant” i koordynatorem regionalnym, który przekazuje informacje o potwierdzeniu lub wykluczeniu istnienia sprzeciwu w Centralnym Rejestrze Sprzeciwów. Przeprowadza niezwykle trudną emocjonalnie rozmowę $\mathrm{z}$ rodziną dawcy $\mathrm{w}$ celu wykluczenia ewentualnego sprzeciwu na dawstwo, który zmarły mógł wyrazić za życia. Jest wsparciem dla rodziny nie tylko do momentu uzyskania autoryzacji pobrania. Koordynator sprawdza czy wszystkie niezbędne badania zostały 
wykonane, a ich wyniki wpisane do systemu informatycznego. Przewiduje trudności w trakcie realizacji zadań i stara się rozwiązać wszystkie napotkane problemy. Koordynuje pracą wielodyscyplinarnych zespołów związanych procesem dawstwa i przeszczepiania. Organizuje salę operacyjną i personel na czas pobrania, a także współpracuje z zespołami pobierającymi narządy. Jest wsparciem dla całego zespołu zaangażowanego w kwalifikację i opiekę nad dawcą. Praca koordynatora nie kończy się w momencie pobrania narządów, promuje on transplantologię i dawstwo narządów w swoim środowisku lokalnym. Jest to zajęcie wymagające dużego zaangażowania w pracę, spędzenia wielu godzin w szpitalu, ale dające ogromną satysfakcję.

\section{Bibliografia/Bibliography:}

1. Antoszkiewicz K., Mańkowski M., Czerwiński J. Pobieranie i przeszczepianie narządów w Polsce w 2015 r., Poltransplant. Biuletyn Informacyjny. 2016;1(24):14-32.

2. Lewandowska D., Hermanowicz M., Przygoda J., Podobińska I., Barczon S., Mańkowski M. Krajowa lista osób oczekujących na przeszczepienie. Poltransplant. Biuletyn Informacyjny. 2016;11(24):35-47.

3. Danek T., Czerwiński J., Kochut W. Sieć szpitalnych koordynatorów transplantacyjnych w Polsce w 2014

r., Poltransplant. Biuletyn Informacyjny. 2014;1(23)144-148.

4. Ustawa z dnia 1 lipca 2005 r. o pobieraniu, przechowywaniu i przeszczepianiu komórek, tkanek i narządów (Dz. U. z 2005r. Nr 169, poz. 1411 ze zm.).

5. Rozporządzenie Ministra Zdrowia w sprawie szczegółowych warunków pobierania, przechowywania i przeszczepiania komórek, tkanek i narządów (Dz. U. z 2016, poz. 1674).

6. Iwańczuk W. Śmierć mózgu. Cornetis. Wrocław 2010.

7. Obwieszczenie Ministra Zdrowia w sprawie kryteriów i sposobu stwierdzenia nieodwracalnego zatrzymania krążenia. (M.P. $2010 \mathrm{nr} 59$ poz. 784).

8. Szkolenie podyplomowe koordynatorów transplantacyjnych. XVIII edycja, Centrum Kształcenia Podyplomowego WUM. Warszawa 2016.

9. Kruszyna T., Mileniak I. Koordynacja pobrania narządów od dawcy zmarłego - krok po kroku. MP. 2009.

10. Saucha W., Maruszewski M., Kucewicz-Czech E. Opieka nad dawcą - rola nie tylko anestezjologa. Kardiochirurgia i Torakochirurgia Polska. 2010;7(4):424-426.

11. Obwieszczenie Ministra Zdrowia z dnia 17 lipca 2007 w sprawie kryteriów i sposobu stwierdzania trwałego nieodwracalnego ustania czynności mózgu. M.P. 2007, nr 46, poz. 547.

12. Jakubowska-Winecka A. Psychologiczne aspekty komunikowania się z rodziną potencjalnego dawcy narządów do przeszczepienia [w:] Rolka H. i wsp. Transplantologia i pielęgniarstwo transplantacyjne. Wyd. Lek. PZWL. Warszawa 2017.

13. Milecka A. Problemy związane z koordynacją pobierania i przeszczepiania narządów i tkanek. Forum Nefrologiczne. 2010;2(3):95-100. 